\title{
RANCANG BANgUn Alat PrakTikUM GERAK JATUH BEBAS DENGAN STOPWATCH OTOMATIS SEDERHANA
}

\author{
Haris Rosdianto ${ }^{1)}$ \\ 1) Sekolah Tinggi Keguruan dan Ilmu Pendidikan (STKIP)Singkawang \\ E-mail: harisrosdianto@yahoo.com
}

\begin{abstract}
Abstrak. Penelitian ini bertujuan untuk mengembangkan media pembelajaran berupa alat dan pedoman praktikum gerak jatuh bebas dengan stopwatch otomatis sederhana. Metode yang digunakan dalam penelitian ini adalah metode penelitian dan pengembangan yang dicetuskan oleh Borg dan Gall. Instrumen yang digunakan pada penelitian ini adalah lembar kuisioner validasi. Hasil validasi alat praktikum oleh ahli alat sebesar $92,86 \%$ yang diinterpretasikan sangat baik. Hasil validasi buku pedoman praktikum oleh ahli materi dan ahli konten sebesar $88,46 \%$ yang diinterpretasikan sangat baik. Hasil uji coba lapangan dengan subjek penelitian 15 orang mahasiswa Prodi Pendidikan Fisika sebesar 87,33\% yang diinterpretasikan sangat baik.
\end{abstract}

Kata Kunci: Pengembangan; Praktikum; Gerak Jatuh Bebas; Stopwatch Otomatis; Relai

\section{PEndahuluan}

Dalam pembelajaran fisika, pendekatan ilmiah melalui kegiatan praktikum adalah penting [1]. Namun di lapangan, proses yang mengarah kepada pendekatan inquiry tersebut jarang sekali dilakukan [2]. Melalui survei yang dilakukan di sejumlah sekolah di Singkawang diketahui bahwa sekitar 33\% sekolah melakukan kegiatan praktikum kurang dari dua kali per semesternya bahkan sekitar $65 \%$ sekolah tidak melakukan praktikum sama sekali sepanjang semesternya. Dari hasil survei juga diperoleh data bahwa sekitar $76,7 \%$ siswa kesulitan dalam memahami konsep gerak jatuh bebas. Sekitar $83,3 \%$ guru mengajarkan konsep gerak jatuh bebas dengan metode ceramah dan hanya sekitar $2,22 \%$ guru yang melakukan praktikum. Hal ini dikarenakan keterbatasan dan kekurangefektifan alat praktikum sehingga siswa kesulitan dalam memahami konsep gerak jatuh bebas [3].

Tujuan dari penelitian ini adalah untuk mempermudah pengambilan data berupa waktu jatuh bebas dengan menggunakan stopwatch yang bisa bekerja secara otomatis, dan data tersebut kemudian diolah untuk mendapatkan nilai percepatan. Percepatan yang dialami benda jatuh bebas disebut percepatan yang disebabkan oleh gravitasi dan diberi simbol $g$ [4]. Di dekat permukaan bumi, besarnya kira-kira 32 $\mathrm{kaki} / \mathrm{s}^{2}$ atau $9,8 \mathrm{~m} / \mathrm{s}^{2}$ atau $980 \mathrm{~cm} / \mathrm{s}^{2}$, dan berarah ke bawah menuju pusat bumi [4].

Jarak yang ditempuh oleh benda untuk mencapai permukaan tanah selama selang waktu $t$ detik dengan mendapat pengaruh percepatan gravitasi sebesar $g$ dapat dinyatakan sebagai berikut:

$$
y=v_{0} t+\frac{1}{2} g t^{2}
$$

di mana $y$ adalah panjang lintasan, $v_{0}$ adalah kecepatan awal saat jatuh, $g$ adalah percepatan gravitasi dan $t$ adalah waktu yang dibutuhkan oleh benda untuk sampai ke tanah [4]. Pada konsep gerak jatuh bebas nilai $v_{0}$ adalah 0 , sehingga persamaannya menjadi:

$$
\begin{gathered}
y=\frac{1}{2} g t^{2} \\
g=\frac{2 y}{t^{2}}
\end{gathered}
$$

Saat ini, percobaan gerak jatuh bebas yang bertujuan untuk menentukan nilai percepatan gravitasi, pengambilan data berupa waktu jatuh benda masih menggunakan stopwatch secara manual [3]. Karena masih manual, maka tingkat kesalahan dalam pengambilan data masih cukup besar. Untuk itu perlu dipikirkan cara alternatif agar tingkat kesalahan dalam pengambilan data praktikum dapat diminimalisir.

Relai adalah saklar yang dioperasikan secara listrik dan merupakan komponen elektromekanik yang terdiri dari 2 bagian utama, yaitu elektromagnet (coil) dan mekanik (seperangkat kontak saklar) [5]. Relai menggunakan prinsip elektromagnetik untuk menggerakkan kontak saklar sehingga dengan arus listrik yang kecil (low power) dapat menghantarkan listrik yang bertegangan lebih tinggi [6], begitu juga sebaliknya. 

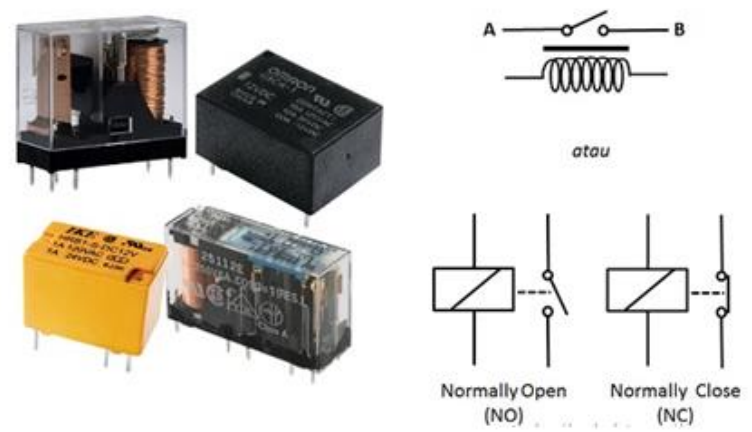

Gambar 1. Bentuk dan simbol relai

Relai yang menggunakan elektromagnet $5 \mathrm{~V}$ dan $50 \mathrm{~mA}$ mampu menggerakan armature relay (yang berfungsi sebagai saklarnya) untuk menghantarkan listrik 220V $2 \mathrm{~A}$. Berdasarkan hal ini, maka relai dapat digunakan sebagai saklar pengoperasian stopwatch secara otomatis.

\section{Metode}

\section{A. Desain Penelitian}

Penelitian ini merupakan penelitian pengembangan yaitu pengembangan media pembelajaran berupa alat dan buku pedoman praktikum gerak jatuh bebas dengan stopwatch otomatis sederhana sebagai alat pengumpul data waktu. Alat praktikum ini diharapkan dapat menjadi alat praktikum alternatif yang lebih akurat dan membantu praktikan mengatasi kesulitan dalam melakukan praktikum. Tingkat kelayakan alat dan buku pedoman praktikum ini diketahui melalui validasi oleh ahli alat, ahli konten dan ahli media. Validasi dilakukan oleh guru mata pelajaran fisika di kota Singkawang dan uji coba penggunaan oleh mahasiswa Prodi Pendidikan Fisika STKIP Singkawang.

Prosedur penelitian yang dilakukan peneliti dalam pengembangan ini diadaptasi dari langkah-langkah pengembangan yang dikembangkan oleh Borg \& Gall dengan pembatasan. Borg \& Gall menyatakan bahwa dimungkinkan untuk membatasi penelitian dalam skala kecil, termasuk membatasi langkah penelitian [7]. Penerapan langkah-langkah pengembangan disesuaikan dengan kebutuhan peneliti. Mengingat keterbatasan waktu dan dana yang dimiliki peneliti, maka langkah-langkah tersebut disederhanakan menjadi tiga langkah pengembangan seperti berikut:

1. Tahap penelitian dan pengumpulan data

2. Tahap pengembangan produk

3. Tahap validasi dan uji coba

Prosedur pengembangan alat praktikum dapat dilihat dalam bagan berikut ini:
Jurnal Ilmu Pendidikan Fisika

Volume 3 Number 1 month March 2018. Page 20-23 p-ISSN: 2477-5959 e-ISSN: 2477-8451

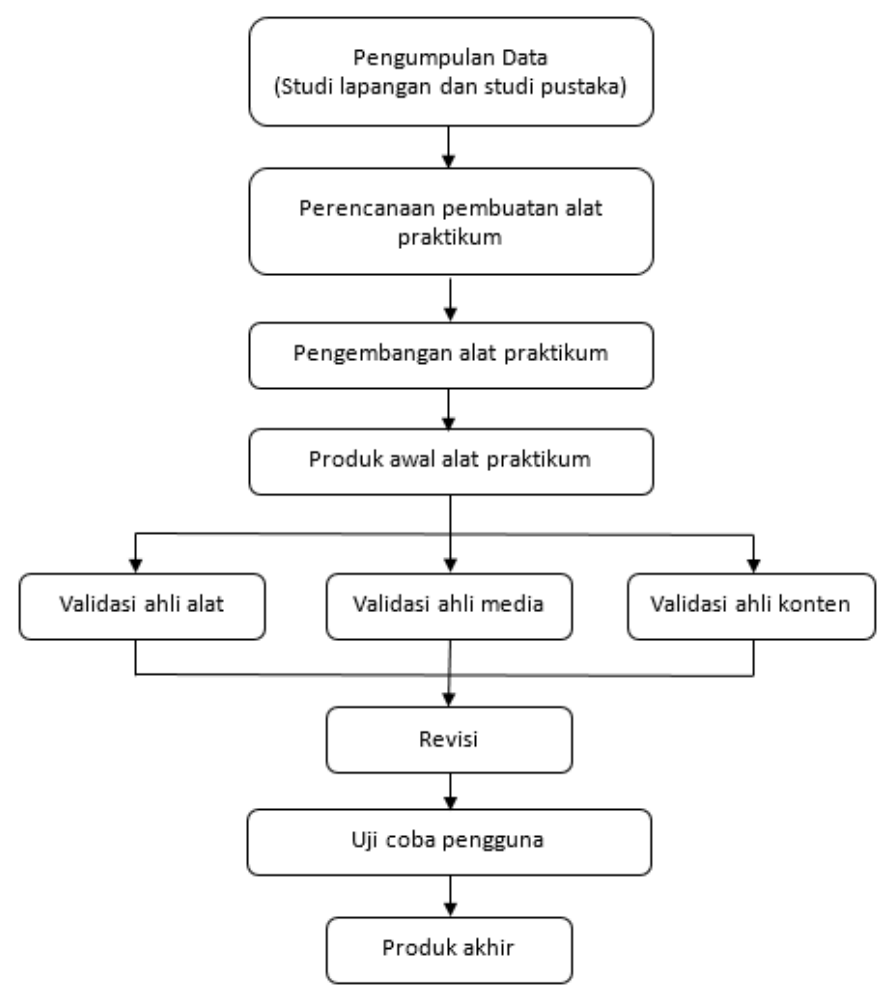

Gambar 2. Bagan prosedur pengembangan

Rancangan alat terdiri dari beberapa instrumen antara lain, kumparan, batang besi, rangkaian relai, stopwatch, sumber tegangan DC dan kabel penghubung. Bahan yang digunakan pada penelitian ini adalah sebuah baut besi.

\section{B. Metode Analisis Data}

Data hasil evaluasi uji efektivitas alat peraga oleh ahli alat, hasil evaluasi panduan praktikum oleh ahli media dan konten dan hasil uji pengguna oleh mahasiswa yang masih dalam bentuk huruf diubah menjadi skor dengan ketentuan yang dapat dilihat dalam tabel 1 berikut.

TABEL 1

KONVERSI PEMBERIAN SKOR DARI HURUF KE ANGKA

\begin{tabular}{cc}
\hline Kategori & Skor \\
\hline Sangat Baik (SB) & 4 \\
Baik (B) & 3 \\
Cukup (C) & 2 \\
Tidak Baik (TB) & 1 \\
\hline
\end{tabular}

Sedangkan untuk menghitung skor rata-rata setiap kriteria yang diambil digunakan persamaan berikut [8]:

$$
\bar{x}=\frac{\sum x}{n}
$$

Keterangan

$\bar{x}=$ skor rata-rata tiap sub aspek

$\sum x=$ jumlah skor tiap sub aspek

$n=$ jumlah penilai 


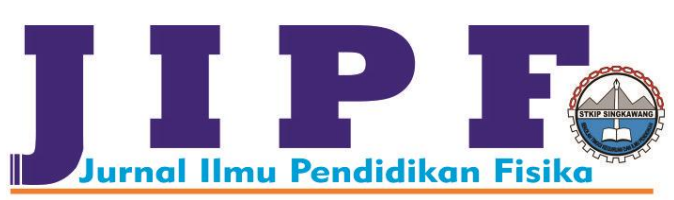

Data yang didapat dari hasil validasi produk berupa alat peraga, panduan eksperimen dan uji pengguna diubah dengan mengubah data menjadi skala empat. Acuan pengubahan skor menjadi skala empat tersebut [2] dapat dilihat pada tabel 2 berikut.

TABEL 2

KONVERSI SKOR MENJADI NILAI SKALA EMPAT

\begin{tabular}{cc}
\hline Rentang rerata & Kriteria \\
\hline $\mathrm{Mi}+1,5 \mathrm{SDi} \leq \mathrm{X} \leq \mathrm{Mi}+3,0 \mathrm{SDi}$ & Sangat Baik \\
$\mathrm{Mi}+0 \mathrm{SDi} \leq \mathrm{X} \leq \mathrm{Mi}+1,5 \mathrm{SDi}$ & Baik \\
$\mathrm{Mi}-1,5 \mathrm{SDi} \leq \mathrm{X} \leq \mathrm{Mi}+0 \mathrm{SDi}$ & Cukup \\
$\mathrm{Mi}-3,0 \mathrm{SDi} \leq \mathrm{X} \leq \mathrm{Mi}-1,5 \mathrm{SDi}$ & Tidak Baik \\
\hline
\end{tabular}

Keterangan:

$\mathrm{X}=$ Skor actual (skor yang dicapai)

$\mathrm{Mi}=$ Rerata skor ideal

$=1 / 2($ Skor tertinggi ideal + skor terendah ideal $)$

SDi $=$ Standar Deviasi skor ideal

$=1 / 6($ Skor trtinggi ideal - skor terendah ideal $)$

Skor tertinggi ideal $=\sum$ butir kriteria $\mathrm{x}$ skor tertinggi

Skor terendah ideal $=\sum$ butir kriteria $\mathrm{x}$ skor terendah

Sedangkan rumus rurntuk menghitung prosentase keidealan adalah dengan menggunaan persamaan berikut:

$\%$ keidealan $=($ skor hasil penilaian $/$ skor maksimum ideal $) \mathrm{x}$ $100 \%$

\section{HASIL DAN PEMBAHASAN}

\section{A. Validasi Alat Peraga}

Berdasarkan penilaian validator terhadap aspek penilaian tampilan alat peraga, aspek teknis pengoperasian alat peraga dan aspek kemanfaatan alat peraga memperoleh skor amat baik di mana interval skornya terletak pada $45,5 \leq X \leq 56$ atau $81,25 \% \leq \mathrm{X} \leq 100 \%$. Dengan demikian alat peraga siap digunakan sebagai media pembelajaran.

TABEL 3

RENTANG RERATA SKOR VALIDASI AHLI ALAT

\begin{tabular}{ccc}
\hline Rentang rerata & Rentang rerata dalam \% & Kriteria \\
\hline $45,5 \leq \mathrm{X} \leq 56$ & $81,25 \% \leq \mathrm{X} \leq 100 \%$ & Sangat Baik \\
$35 \leq \mathrm{X} \leq 45,5$ & $62,5 \% \leq \mathrm{X} \leq 81,25 \%$ & Baik \\
$24,5 \leq \mathrm{X} \leq 35$ & $43,75 \% \leq \mathrm{X} \leq 62,5 \%$ & Cukup \\
$14 \leq \mathrm{X} \leq 24.5$ & $25 \% \leq \mathrm{X} \leq 47,75 \%$ & Tidak Baik \\
\hline
\end{tabular}

Skor keidealan untuk aspek tampilan alat peraga 93,75\%, skor keidealan untuk aspek teknis pengoperasian alat peraga $90 \%$, skor keidealan untuk aspek kemanfaatan alat peraga 95\%. Sedangkan untuk keseluruhan uji validasi alat peraga skor keidealannya adalah 92,86\%. Gambar nilai rata-rata validasi alat peraga oleh ahli alat dapat dilihat pada gambar 3.
Jurnal Ilmu Pendidikan Fisika

Volume 3 Number 1 month March 2018. Page 20-23 p-ISSN: 2477-5959 e-ISSN: 2477-8451

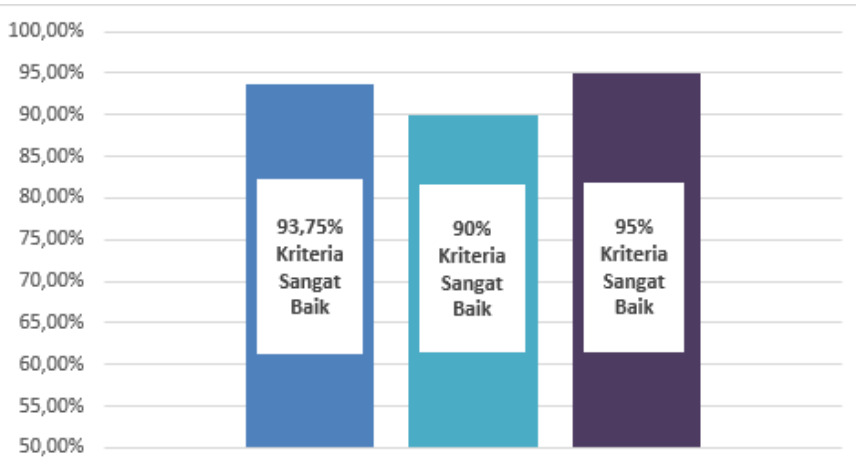

- Tampilan Alat Peraga @ Teknis Pengoperasian Alat Peraga @ Kemanfaatan Alat Peraga

Gambar 3. Grafik nilai rata-rata uji validasi alat peraga

\section{B. Validasi Panduan Eksperimen}

Berdasarkan penilaian validator terhadap aspek kelayakan isi, aspek penyajian, aspek kebahasaan dan aspek gambar memperoleh skor amat baik di mana interval skornya terletak pada $42,25 \leq X \leq 52$ atau $81,25 \% \leq X \leq 100 \%$. Dengan demikian panduan eksperimen siap digunakan sebagai media pembelajaran.

TABEL 4

RENTANG RERATA SKOR VALIDASI AHLI MEDIA DAN AHLI MATER

\begin{tabular}{ccc}
\hline Rentang rerata & Rentang rerata dalam \% & Kriteria \\
\hline $42,25 \leq X \leq 52$ & $81,25 \% \leq X \leq 100 \%$ & Sangat Baik \\
$32,5 \leq X \leq 42,25$ & $62,5 \% \leq X \leq 81,25 \%$ & Baik \\
$22,75 \leq X \leq 32,5$ & $43,75 \% \leq X \leq 62,5 \%$ & Cukup \\
$13 \leq X \leq 22,75$ & $25 \% \leq X \leq 47,75 \%$ & Tidak Baik \\
\hline
\end{tabular}

Skor keidealan untuk aspek kelayakan isi 90\%, skor keidealan untuk aspek penyajian 87,50\%, skor keidealan untuk aspek kebahasaan 91,67\%, skor keidealan untuk aspek gambar $83,33 \%$. Sedangkan untuk keseluruhan uji validasi panduan ekesperimen $88,46 \%$. Gambar nilai rata-rata validasi panduan eksperimen oleh ahli media dan ahli materi dapat dilihat pada gambar 4 .

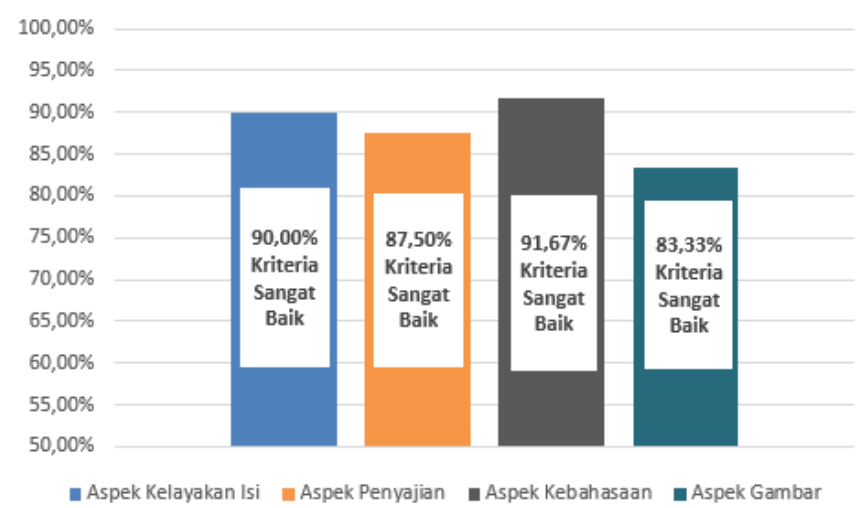

Gambar 4. Grafik nilai rata-rata uji validasi panduan eksperimen 


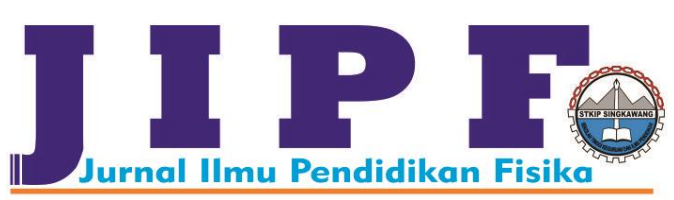

C. Hasil Validasi Uji Pengguna

Berdasarkan penilaian uji pengguna memperoleh skor amat baik di mana interval skornya terletak pada $32,5 \leq \mathrm{X} \leq 40$ atau $81,25 \% \leq X \leq 100 \%$. Dengan demikian alat peraga dan panduan eksperimen siap digunakan sebagai media pembelajaran.

TABEL 5

RENTANG RERATA SKOR VALIDASI UJI PENGGUNA

\begin{tabular}{ccc}
\hline Rentang rerata & Rentang rerata dalam \% & Kriteria \\
\hline $32,5 \leq X \leq 40$ & $81,25 \% \leq X \leq 100 \%$ & Sangat Baik \\
$25 \leq X \leq 32,5$ & $62,5 \% \leq X \leq 81,25 \%$ & Baik \\
$17,5 \leq X \leq 25$ & $43,75 \% \leq X \leq 62,5 \%$ & Cukup \\
$10 \leq X \leq 17.5$ & $25 \% \leq X \leq 47,75 \%$ & Tidak Baik \\
\hline
\end{tabular}

Jurnal Ilmu Pendidikan Fisika

Volume 3 Number 1 month March 2018. Page 20-23 p-ISSN: 2477-5959 e-ISSN: 2477-845I

Uji pengguna dilakukan oleh 15 mahasiswa untuk mengetahui respon mahasiswa setelah mahasiswa melakukan praktikum gerak jatuh bebas dengan stopwatch otomatis sederhana. Mahasiswa mengisi lembar evaluasi dengan 10 pertanyaan. Data hasil evaluasi uji pengguna oleh mahasiswa diperoleh skor keidealan untuk keseluruhan uji pengguna adalah $87,33 \%$. Grafik hasil evaluasi uji pengguna oleh mahasiswa dapat dilihat pada gambar 5 .

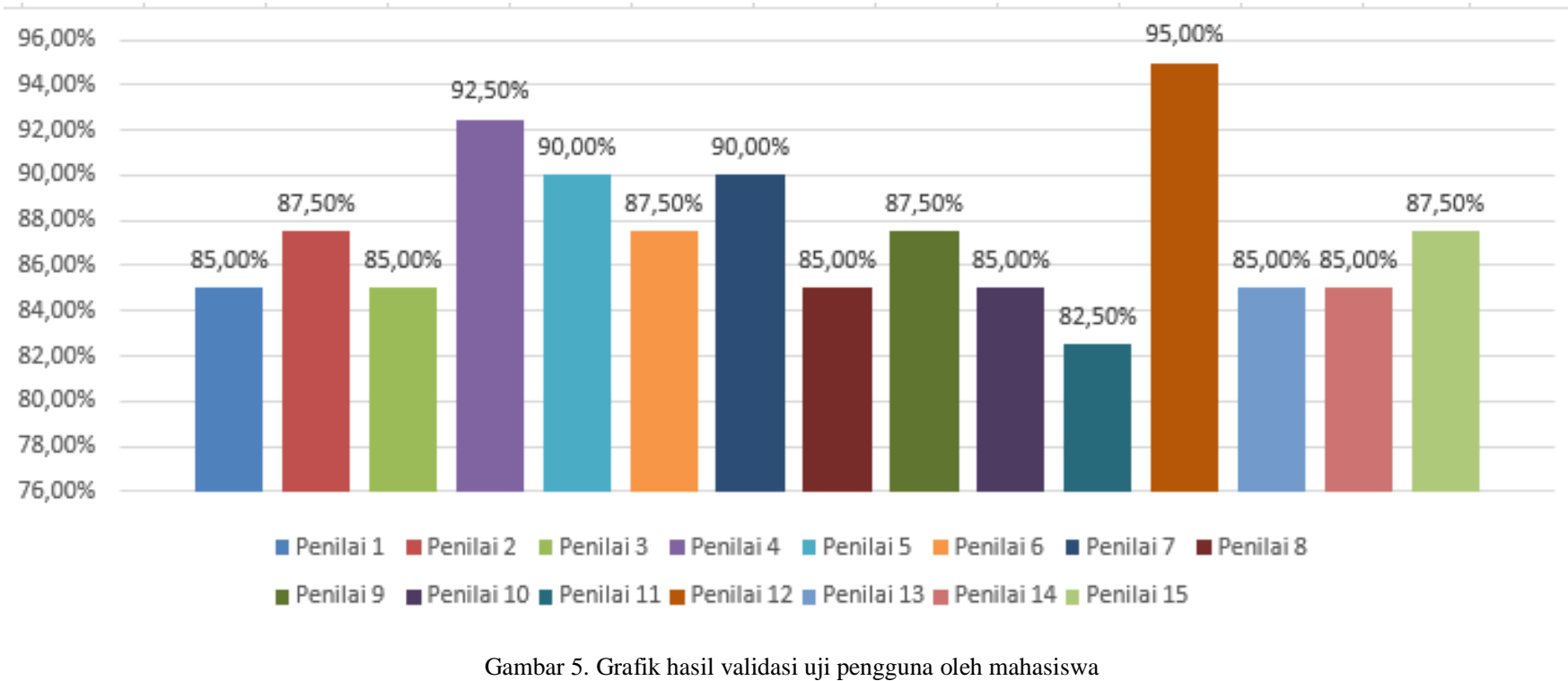

\section{KESIMPULAN}

Pada penelitian ini telah berhasil dikembangkan media pembelajaran alternatif untuk menganalisis fenomena gerak jatuh bebas. Media yang dikembangkan berupa alat dan buku pedoman praktikum gerak jatuh bebas dengan stopwatch otomatis sederhana yang telah divalidasi dengan interpretasi sangat baik, dan telah diujicobakan kepada mahasiswa dengan hasil uji coba yang sangat baik.

\section{DAFTAR PUSTAKA}

[1] Anugrah, M. I., Serevina, V., \& Nasbey, H. (2015). Pengembangan Alat Praktikum Medan Magnet Sebagai Media Pembelajaran Fisika SMA. Prosiding Seminar Nasional Fisika (E-Journal) SNF2015 (pp. 125-130). Jakarta: Universitas Negeri Jakarta.

[2] Rosdianto, H., \& Toifur, M. (2017). Implementasi Teori Distribusi Probabilitas Gaussian Pada Kualitas Rangkaian Penyearah Gelombang Penuh. Spektra: Jurnal Fisika dan Aplikasinya, 2(1), 83-90.
[3] Rosdianto, H. (2017). Penentuan Percepatan Gravitasi Pada Percobaan Gerak Jatuh Bebas Dengan Memanfaatkan Rangkaian Relai. Spektra: Jurnal Fisika dan Aplikasinya, 2(2), 107-112.

[4] Halliday, D., \& Resnick, R. (1985). Fisika Jilid 1. (P. Silaban \& E. Sucipto, Eds.) (3rd ed.). Jakarta: Erlangga.

[5] Neamen, D. A. (2003). Semiconductor Physics and Devices: Basic Principles (3rd ed.). New York: McGraw-Hill.

[6] Boylestad, R., \& Nashelsky, L. (2002). Electronic Devices and Circuit Theory (7th ed.). New Jersey: Prentice Hall.

[7] Gall, M. D., Gall, J. P., \& Borg, W. R. (2007). Educational Research: An Introduction (8th ed.). Boston: Pearson Education, Inc.

[8] Sugiyono. (2007). Statistika Untuk Penelitian (12th ed.). Bandung: Alfabeta. 